\title{
DONOR ANONYMITY IN CANADA: ASSESSING THE OBSTACLES TO OPENNESS AND CONSIDERING A WAY FORWARD
}

\author{
VANESSA GRUBEN AND ANGELA CAMERON*
}

\begin{abstract}
This article discusses donor anonymity in Canada and the need for law reform in this area. Currently, assisted reproduction is regulated by both the provincial and federal governments, meaning this area is regulated in a piecemeal fashion. Disclosure of donor identifying and non-identifying factors is restricted to limited information, utilized only to keep statistical records. Due to the law limiting identifying information, donor-conceived persons struggle in their attempt to discover their genetic origins. Further, provincial family law does not recognize third party reproduction, which leaves modern family units unprotected. A definition of openness in gamete donation is given in Part II. Part III addresses the law-making and assisted reproduction difficulties arising from the division of powers. Part IV analyzes the potential impact of federal prohibitions on the purchase of sperm and eggs and whether disclosing a donor's identity will negatively impact gamete supply in Canada. The final two sections discuss the failure of provinces to enact family laws which protect the parental status of intended parents and how past cases under the Canadian Charter of Rights and Freedoms have been challenging for donor-conceived persons. The authors propose that reform should be dealt with by the legislature in four areas: provincial family law reform where necessary; robust and meaningful public consultation; interprovincial cooperation if possible; and, consideration of law reform in other jurisdictions.
\end{abstract}

\section{TABLE OF CONTENTS}

I. INTRODUCTION . . . . . . . . . . . . . . . . . . . . . 665

II. OPENNESS IN GAMETE DONATION: A CANADIAN APPROACH . . . . . . . 666

A. Why OPENNESS? ......................... 666

B. What are the Current Practices around ANonymity? . . . . 667

III. REgUlATING AsSisted HUMAN REPRODUCTION:

DIVISION OF POWERS . . . . . . . . . . . . . . . . . . . 668

IV. Prohibition on Purchase of SPERM AND EgG $\ldots \ldots \ldots \ldots \ldots \ldots 672$

A. The United Kingdom: Altruistic And Open DonAtion . . . . 673

V. FAMILY LAW REFORM . . . . . . . . . . . . . . . . . . . . . . . . . . . . . . 674

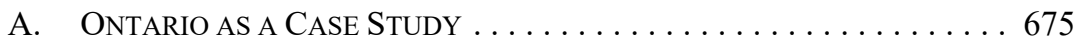

VI. THE CHARTER ................................ 676

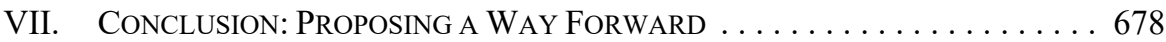

\section{INTRODUCTION}

Donor anonymity has been hotly debated in Canada. In recent years, there has been a renewed effort to de-anonymize sperm and egg donation for the reproductive use of third

Vanessa Gruben is an Associate Professor at the Faculty of Law, University of Ottawa and a member of the Centre for Health Law, Policy and Ethics. Dr. Angela Cameron is an Associate Professor at the Faculty of Law, University of Ottawa. She currently holds the Greenberg Chair in Women and the Legal Profession. The authors would like to thank Meaghan Patrick for her excellent research assistance with this article. 
parties. ${ }^{1}$ To date, these efforts have been unsuccessful. This article addresses several obstacles which continue to block law reform in Canada. These obstacles illustrate that this is a multifaceted problem. In order for meaningful law reform to occur in this area, we argue that donor anonymity is best dealt with comprehensively by the legislature rather than in a piecemeal fashion by the courts.

In Part II, we define what we mean by openness in gamete donation. In Part III, we address the difficulties arising from the division of powers. The regulation of assisted human reproduction (AHR) is shared by both federal and provincial governments. The regulation of donor anonymity falls within provincial law-making authority, but there are a number of federal laws which impact regulation in this area. In Part IV, we examine the potential impact of federal prohibitions on the purchase of sperm and eggs and the question of whether requiring donors to disclose their identity will have a further negative impact on gamete supply. In Part V, we discuss the failure of several provinces to enact family laws which protect the parental status of intended parents. This has a particularly profound impact on women-led families. In Part VI, we consider how past cases under the Canadian Charter of Rights and Freedoms have made constitutional claims that donor-conceived persons have the right to know their genetic origins quite challenging. ${ }^{2}$ We conclude by offering our view of what needs to be done to facilitate meaningful law reform regarding donor anonymity in Canada. We argue that this law reform should begin with reform of family legislation governing parentage (where necessary). In our view, law reform must include meaningful public consultation given the diverse interests of donors, intended parents, and donorconceived people. Finally, while it is not necessary, we believe that interprovincial cooperation on this issue would be highly beneficial as it will render an information collection and disclosure regime more effective.

\section{Openness in GaMete Donation: A Canadian Approach}

\section{A. Why OPENNESS?}

As we have stated elsewhere, ${ }^{3}$ we strongly support legislative moves towards openness in gamete donation in Canada. This article outlines some of the obstacles to openness, including several pre-emptive law and policy changes that we believe must be in place before de-anonymization takes place. ${ }^{4}$ There are a wide variety of rationales behind the recent push towards openness in gamete donation. While we support legal and policy moves in this direction, we do not endorse some of the reasoning posited by several commentators in the field. In particular, we disagree with those who characterize anonymous gamete donation as

This article treats only the donation of sperm and ova, not the donation of embryos.

Part I of the Constitution Act, 1982, being Schedule B to the Canada Act 1982 (UK), 1982, c 11 [Charter].

3 Angela Cameron, Vanessa Gruben \& Fiona Kelly, "De-Anonymising Sperm Donors in Canada: Some Doubts and Directions" (2010) 26:1 Can J Fam L 95.

$4 \quad$ This article deals only with prospective openness, and does not treat the more complex circumstances of retroactive de-anonymization. 
a catalyst for mental health concerns in donor-conceived people, ${ }^{5}$ and those who would characterize knowing the identity of your biological progenitor as a "right" either under the Canadian Constitution, or under international human rights law. ${ }^{6}$

Rather, we support legal and policy reform towards openness based on three main rationales: access to ongoing health information for donor-conceived people from gamete donors $;^{7}$ the ability of sexually active donor-conceived people to determine if their sexual partner is genetically related to them ${ }^{8}$ and the release of identifying information to donorconceived people to alleviate the stress, anxiety, and frustration that may be caused by not knowing their genetic origins.

\section{B. What are the Current Practices Around Anonymity?}

There are important gendered differences between sperm and egg donation. The processes of donation, regulation, and availability are different in each case, as are the impacts on the donors themselves. ${ }^{9}$ For these reasons we know more about sperm donation than we do about egg donation. This gap in knowledge as between egg and sperm donation is further exacerbated by significant changes in the practice of egg donation over the past few years. Since 2012, it has been possible to freeze eggs for donation. Prior to this time fresh eggs were required to create an embryo. As a result, frozen eggs are currently subject to less regulation than sperm, whose collection, frozen storage, and distribution has been the subject of federal regulation for decades. ${ }^{10}$

Like many aspects of assisted human reproduction which remain unregulated in Canada, few rules governing gamete donation and the disclosure of identifying information exist. For example, many provincial privacy statues limit the disclosure of a gamete donor's identifying information. ${ }^{11}$ Perhaps the most glaring gap in regulation is the absence of any centralized

5 Recent empirical research shows that it is more often secrecy, not anonymity, that may cause harmful identity issues for donor-conceived people. Secrecy is entirely concealing the fact that donor-conceived people are born from donated gametes, which can cause shock and upset if this fact is discovered inadvertently. Anonymity, by contrast, is where donor-conceived people know they are conceived using donor gametes, but do not have identifying information about the donor. They may have non-identifying information such as age, hobbies, hair colour, childhood photos, etc. See generally Ilke Turkmendag, “The Donor-Conceived Child's 'Right to Personal Identity': The Public Debate on Donor Anonymity in the United Kingdom" (2012) 39:1 JL \& Soc'y 58. And regarding women-led families in particular, see NLLFS, US National Longitudinal Lesbian Family Study (2012), online <www.nllfs.org $>$.

6 See e.g. Juliet Guichon, Ian Mitchell \& Michelle Giroux, eds, The Right to Know One's Origins: Assisted Human Reproduction and the Best Interests of Children (Brussels: Academic \& Scientific Publishers, 2012). To characterize access to this information as a 'right' fails, in our opinion, to balance other, equally important interests such as protecting the privacy of women who become pregnant following incest, sexual violence, or sexual relationships outside of common law or marriage relationships.

$7 \quad$ See Vincent Couture et al, "Strengths and Pitfalls of Canadian Gamete and Embryo Donor Registries: Searching for Beneficient Solutions" (2014) 28 Reproductive Biomedicine Online 369.

8 Naomi Cahn, "Accidental Incest: Drawing the Line - or the Curtain? — for Reproductive Technology" (2009) 32 Harv JL \& Gender 59 at 106.

$9 \quad$ For details, see Vanessa Gruben, "Women as Patients, Not Spare Parts: Examining the Relationship Between the Physician and Women Egg Providers" (2013) 25:2 CJWL 249 [Gruben, "Women as Patients"].

$10 \quad$ Food and Drug Regulations, CRC, c 870.

11 See Vanessa Gruben, "Assisted Reproduction Without Over-Collection: Fair Information Practices and the Assisted Human Reproduction Agency of Canada” (2009) 17:1 Health LJ 229 [Gruben, “Assisted Reproduction"]. 
national or provincial registry to collect, store, and disclose gamete donor information and identity.

Couples and individuals seeking donated gametes in Canada currently have several options. The first option is anonymous sperm, meaning there is no available identifying information from the donor at any time to either the parent(s) or donor-conceived people. The second option is identity-release sperm, whereby the donor agrees for his identity to be disclosed at a specific age, often $18 .^{12}$ Finally those seeking donated sperm may wish to use a known donor. This practice is permitted so long as the donor has not had sexual contact with another man, or he is the sexual partner of the woman seeking fertility treatments. ${ }^{13} \mathrm{As}$ we will discuss below, however, there may be additional family law barriers to using a known donor in certain provinces.

There are also several options for the use of eggs from a third party. Until 2012, virtually all donated eggs were fresh and thus it was more difficult to obtain donor eggs for reproductive purposes. ${ }^{14}$ Egg donors who provide fresh eggs can be either anonymous or known. ${ }^{15}$ The advent of egg freezing technology has made donor eggs more accessible for third party reproduction. We note that, unlike the donation of fresh eggs, which may be anonymous, known, or identity release, most frozen donor eggs appear to be anonymous only.

As discussed below, open gamete donation would be facilitated by a clear delineation of who is, and who is not, a legal parent for the purposes of access, custody, inheritance, and child support. It would also be facilitated through the creation of a national registry ${ }^{16}$ that allowed for ongoing, non-identifying disclosure of relevant medical information from gamete donors, ${ }^{17}$ the ability to ascertain if potential sexual partners are genetically related without releasing identifying information, and the capacity to release identifying information at a given time in the case of identity-release donors.

\section{Regulating AsSisted Human Reproduction: DIVISION OF POWERS}

The first legal obstacle to moving to a more open system of gamete donation relates to the division of powers in Canada. That is, which level of government has the authority to make laws with respect to the conditions for donation of human sperm and ova? A 2010 Supreme Court of Canada decision declaring much of assisted human reproduction to fall within provincial law-making authority has made it challenging for provincial governments to

Most identity- release sperm is imported from the United States, making it difficult to enforce the release of the identifying information across borders. There is currently no Canadian law that mandates this disclosure.

13 Angela Cameron, "A Chip Off the Old (Ice) Block?: Women-led Families, Sperm Donors and Family Law" in Jennifer M Kilty, ed, Within the Confines: Women and the Law in Canada (Toronto: Canadian Scholar's Press, 2014) at 250 [Cameron, "A Chip Off the Old (Ice) Block"]. Egg vitrification is a new practice, which may result in increased availability of anonymous, cryopreserved eggs. At this time it is an expensive practice, with as yet fully untested impacts on fertility.

15 Gruben, "Women as Patients, supra note 9 at 253.

16 Or a series of interconnected provincial and territorial registries as we see in adoption and organ donation.

17 Such as emerging genetic disorders. 
undertake a national approach to collecting and disseminating donor information. ${ }^{18}$ Since it is now up to the provinces to legislate in this area, there is a possibility of interprovincial jurisdiction shopping for donated gametes.

In Canada, with the exception of the parentage issues arising from third party reproduction, which is clearly provincial, there was initially some uncertainty about which level of government had the authority to make laws governing assisted human reproduction. ${ }^{19}$ The federal government regulated assisted human reproduction comprehensively by virtue of the Assisted Human Reproduction Act (AHRA), ${ }^{20}$ but after lengthy litigation much of the federal Act was declared to fall outside federal law-making authority. ${ }^{21}$ As a result, it only recently became clear that the provincial legislatures had the authority to enact laws in this area. A brief review of the history of the federal law is useful to better illustrate how we arrived at this point in Canada and why the division of powers represents a legal obstacle to law reform regarding donor anonymity.

From the outset, Parliament undertook to regulate assisted human reproduction comprehensively. ${ }^{22}$ It struck a Royal Commission on New Reproductive Technologies, which made more than 250 recommendations in the $1990 \mathrm{~s},{ }^{23}$ and in 2004 Parliament enacted the AHRA.

Parliament sought to enact the AHRA by virtue of its criminal law power. ${ }^{24}$ Parliament has a broad authority under this power to enact laws regarding public health and morality. ${ }^{25}$ Parliament invoked its criminal law power in the AHRA by creating two categories of activities: prohibited activities and controlled activities. ${ }^{26}$ Prohibited activities, such as purchasing human sperm and eggs, could not occur under any circumstances. ${ }^{27}$ By contrast, controlled activities could be undertaken with a licence only. ${ }^{28}$ Breaches of both were punishable by criminal penalties: significant fines and possible prison sentences. ${ }^{29}$

Reference re Assisted Human Reproduction Act, 2010 SCC 61, [2010] 3 SCR 457 [AHRA Reference]. Most commentators argue that it is shared between the federal and provincial governments. Martha Jackman, "The Constitution and the Regulation of New Reproductive Technologies" in Royal Commission on New Reproductive Technologies, Legal and Ethical Issues in New Reproductive Technologies: Pregnancy and Parenthood (Ottawa: Supply and Services Canada, 1994) at 2, 18; Sheila L Martin, Women's Reproductive Health, the Canadian Charter of Rights and Freedoms, and the Canada Health Act (Ottawa: Canadian Advisory Council on the Status of Women, 1989) at 2; Glenn Rivard \& Judy Hunter, The Law of Assisted Human Reproduction (Markham: LexisNexis Canada, 2005) at 29 .

Assisted Human Reproduction Act, SC 2004, c 2 [AHRA].

AHRA Reference, supra note 18.

See Vanessa Gruben \& Angela Cameron, "Quebec's Constitutional Challenge to the Assisted Human Reproduction Act: Overlooking Women's Reproductive Autonomy?" in Stephanie Paterson, Francesca Scala \& Marlene K Sokolan, eds, Fertile Ground: Exploring Reproduction in Canada (Montreal: McGill-Queens Press, 2012) 125 for details of the various attempts to pass this legislation. Canada, Royal Commission on New Reproductive Technologies, Reproductive Technologies: Royal Commission Final Report (Ottawa: Supply and Services Canada, 1994).

AHRA Reference, supra note 18.

Gruben \& Cameron, supra note 22.

AHRA, supra note 20. Prohibited activities are found in the current Act at section 5 and controlled activities at section 10 in the original Act.

Ibid, s 5 .

Ibid, formerly s $10(1)$.

Ibid, formerly ss 60 (a) - (b). 
Among the controlled activities was a set of provisions regarding information collection use and disclosure requirements. ${ }^{30}$ The $A H R A$ protected donor anonymity by only requiring the disclosure of non-identifying information to donor-conceived persons. ${ }^{31}$ Identifying information about the donor could only be disclosed with the consent of the donor. The AHRA required the donor to provide both identifying and non-identifying information, known as "health reporting information," to an Agency, the Assisted Human Reproduction Agency of Canada. The Agency was responsible for creating a registry, which had several purposes, including the disclosure of non-identifying information to donor-conceived people. The AHRA also authorized two individuals who suspected they were donor-conceived and were considering an intimate relationship to contact the Agency to determine whether they were genetically related.

Shortly after the AHRA came into force in 2004, the Attorney General of Quebec (AGQ) brought a reference challenging it on the basis that the AHRA fell outside the legislative authority of Parliament. While conceding that the prohibitions on purchasing reproductive materials and services fell within the federal government's criminal law power, the AGQ argued that many of the provisions dealt with health matters, which generally falls to the provinces to legislate. ${ }^{32}$ The AGQ succeeded in the Quebec Court of Appeal. ${ }^{33}$

The case was appealed to the Supreme Court of Canada. In 2010, the Supreme Court in a badly split decision ruled that much of the Act, including the information provisions, fell within the law-making authority of the provinces because they relate to the regulation of health and health professionals. ${ }^{34}$ Shortly after the Court's decision, Parliament repealed these provisions and also dismantled the Agency, as its mandate and role had been significantly reduced due to the Court's decision. ${ }^{35}$ This effectively removed the federal law mandating donor anonymity, leaving only the provincial and territorial privacy statues to fulfill this function. ${ }^{36}$

Since the Supreme Court of Canada's decision in 2010, the provincial legislatures have, for the most part, failed to regulate in this area, and have not filled the legislative void around donor identity and information. A couple of provinces have enacted legislation relating to assisted human reproduction. ${ }^{37}$ But these laws have, for the most part, focused on funding of assisted human reproduction, and, in particular, in vitro fertilization (IVF). The Quebec government created a very generous funding scheme shortly after the Supreme Court's decision. ${ }^{38}$ While there were very few provisions related to information collection, the publicly funded scheme did require the use of anonymous sperm and egg donors. This

Ibid, formerly ss 14-18.

Gruben, "Assisted Reproduction," supra note 11.

AHRA, supra note 20 , ss 8-19, 40-53, 60, 61, 68.

AHRA Reference, supra note 18.

Ibid.

Jobs, Growth and Long-Term Prosperity Act, SC 2012, c 19, s 713.

Anonymity is also facilitated by policy and practice: there is no registry in existence to collect, store, and distribute identifying and non-identifying information, nor do individual doctors performing Assisted Reproductive Technology (ART) procedures collect this information.

37 Quebec, British Columbia, and Ontario have undertaken the most comprehensive amendments, see e.g. Family Law Act, SBC 2011, c 25; Children's Law Reform Act, RSO 1990, c C12, Part I.

38 Stefanie Carsley, "Funding In Vitro Fertilization: Exploring the Health and Justice Implications of Quebec's Policy" (2012) 20:3 Health L Rev 15 
funding policy was recently repealed following a change in government which was concerned about its high cost. ${ }^{39}$

More recently, Ontario has introduced a policy which pays for one stimulated cycle of IVF. ${ }^{40}$ The Ontario scheme simply allocates a certain number of cycles to the individual fertility clinics, who will decide how they will be allocated. ${ }^{41}$ There is no accompanying regulatory regime for assisted human reproduction. Third party reproduction is clearly contemplated by the funding scheme which provides funding for every Ontarian regardless of whether IVF is needed on the basis of sexual orientation, family status, or disability. Yet the scheme does not cover the costs associated with the shipping and storage of third party gametes. And there is no regulation of donor anonymity or legislation provisions governing information disclosure to donor-conceived persons.

Why have the provincial legislatures failed to address donor anonymity? Although the provincial legislatures have largely been silent, we can speculate on a few reasons.

First, the use of AHR and donor gametes has historically been stigmatized. ${ }^{42}$ Much secrecy has surrounded the use of the donated gametes. ${ }^{43}$ While a great deal of work has been done to overcome secrecy in this area, the provincial legislatures' failure to act may be rooted in traditional and harmful approaches to third party reproduction. Empirical research in the United Kingdom and Europe has shown that opposite sex couples often experience shame and stigma around infertility, and as a result may choose to keep the genetic origins of their donor-conceived children secret. ${ }^{44}$ Moving towards a more open system would eliminate this option, requiring more education and support for intended parents using donated gametes.

Second, there may be a concern that provincial action would be ineffective. Prohibiting donor anonymity in one province may simply result in individuals going to other provinces where anonymous gametes are available. Indeed, this concern about whether a ban would

Bill 20, An Act to enact the Act to promote access to family medicine and specialized medicine services and to amend various legislative provisions relating to assisted procreation, $1 \mathrm{st}$ Sess, $41 \mathrm{st} \mathrm{Leg}$, Quebec, 2015 . Treatments for Ontario Families"(1 October 2015), online: $<$ https://news.ontario.ca/mohltc/en/2015/10/ improving-access-to-fertility-treatments-for-ontario-families-1.html $>$.

Ontario, Ministry of Health and Long-Term Care, News Release, "Ontario Announces 50 Clinics Offering Government-Funded Fertility Treatments" (21 December 2015), online: <https://news. ontario.ca/mohltc/en>. See also Ontario, Ministry of Health and Long-Term Care, "Fertility Services," online: < health.gov.on.ca/en/public/programs/ivf/>.

Supra note 22.

See Turkmendag, supra note 5 .

Petra Nordqvist \& Carol Smart, Relative Strangers: Family Life, Genes and Donor Conception (London: Palgrave Macmillan, 2014); Claes Gottlieb, Othon Lalos \& Frank Lindblad, "Disclosure of Donor Insemination to the Child: The Impact of Swedish Legislation on Couples' Attitudes" (2000) 15:9 Human Reproduction 2052. This can be contrasted with women-led families who almost always disclose donor conception in the course of explaining family formation to their children. See Brewaeys et al, "Donor Insemination: Child Development and Family Functioning in Lesbian Mother Families" (1997) 12:6 Human Reproduction 1349 at 1356; Fiona MacCallum \& Susan Golombok, "Children Raised in Fatherless Families from Infancy: A Follow Up of Children of Lesbian and Single Heterosexual Mothers at Early Adolescence" (2004) 45:8 J Child Psychology \& Psychiatry 1407. 
be effective also extends to the ability of individuals to go to the US to use anonymous gametes. $^{45}$

The third possible reason is the cost and effort associated with setting up a registry system that would ensure donor information is collected and disclosed to donor-conceived individuals. Currently, there is no mandatory collection of information about assisted human reproduction in Canada. All information collection is done on a voluntary basis by the clinics, does not relate to donors, and is not for the purpose of disclosure of information to donor-conceived persons. ${ }^{46}$ Instead, information collection is largely focused on success rates: the number of IVF cycles, the age of patients, and so on. In Ontario, clinic data can be linked to live births, but again the purpose of these efforts is currently limited to traceability and not for the purpose of information disclosure. ${ }^{47}$

\section{Prohibition on Purchase of SPerm and EgGS}

The second possible legal obstacle that stands in the way of more open gamete donation is related to the federal prohibition on the purchase of sperm or eggs in Canada. ${ }^{48}$ Section 7 of the AHRA states that "[n]o person shall purchase, offer to purchase or advertise for the purchase of sperm or ova from a donor or a person acting on behalf of a donor." 49 Notably, section 12 does allow the reimbursement of receiptable expenses. Despite the fact that the AHRA has been in force since 2004, this provision is not yet in force and there are still no regulations defining what constitutes an "expenditure" under section $12 .^{50}$ The Canadian Standards Association, seeking to fill this gap, has proposed a guideline for the reimbursement of expenses. The proposed guideline is currently under review and it is unclear what effect it would have if and when it is finalized. ${ }^{51}$

Some have argued that placing further restrictions on gamete donation will eliminate the small pool of donors that is currently available. ${ }^{52}$ Anonymity is often framed as the price we have to pay in order to have a supply of altruistically donated gametes, and if we demand that donors give their gametes freely and reveal their identity they will cease donating. in Canada" (2013) 41:1 JL Med \& Ethics 224.

Joanne Gunby, Canadian Fertility and Andrology Society, Assisted Reproductive Technologies (ART) in Canada: 2012 Results from the Canadian ART Register (Montreal 2012), online: $<\mathrm{https} / / \mathrm{cfas} . \mathrm{ca} / \mathrm{wp}-$ content/uploads/2014/12/CARTR 2012.pdf>.

Ontario, Better Outcomes Registry \& Network, Born and Growing: Annual Report 2012-14 (Ottawa: BORN, 2015), online: $<$ https://www.bornontario.ca/assets/documents/specialreports/121187\%20Final $\% 20 \mathrm{Web} \% 20-\% 20$ English.pdf $>$.

The prohibition on purchasing gametes is rooted in a bioethical position that rejects the commercialization and commodification of human life. As feminists we support this position, and support a more open gamete donation system rooted in altruistic donation. AHRA, supra note $20, \mathrm{~s} 7$.

50 Dave Snow, Françoise Baylis \& Jocelyn Downie, "Why the Government of Canada Won't Regulate Assisted Human Reproduction: A Modern Mystery" (2015) 9:1 McGill JL \& Health 1 at 4.

$51 \quad$ Alison Motluk, "Reimbursement Discussions Exclude Surrogates, Donors" (2016) 188:1 CMAJ E7.

52 
Indeed, the prohibition on purchase is often blamed for the very low number of donors in Canada. At last count there was only 41 Canadian sperm donors. ${ }^{53}$ Less is known about egg donation in Canada. There is, however, credible evidence that egg donors in Canada are already being paid, beyond receiptable expenses, for their eggs, contrary to the AHRA prohibitions. ${ }^{54}$ As a result of this shortage of donors, most Canadians purchase gametes from other countries. Indeed, the robust trade in reproductive materials across the US border is well-documented. ${ }^{55}$

A small preliminary study, however, shows that a large percentage of men who have already donated sperm in Canada have done so for altruistic rather than commercial reasons.$^{56}$ It is difficult to predict the impact greater openness will have on egg donation. This is, in part, because of the important differences between egg and sperm donation and the need for further empirical research on egg donation. In addition, the advent of egg freezing will likely reduce the use of third party eggs, but it is difficult to gauge the impact given the newness of this technology. ${ }^{57}$ But there is hope that a properly managed system of open, altruistic gamete donation would ultimately yield results similar to the UK, described below.

\section{A. The United Kingdom: Altruistic And Open Donation}

Whether allowing donors to be paid would increase the supply of sperm is difficult to predict. If we examine other jurisdictions with similar bans on commercialization and anonymity, such as the UK it appears there may be open, altruistic models that have met with some success. The UK is one of at least 11 Western jurisdictions where donor anonymity has been eliminated by legislation. ${ }^{58}$ Jurisdictions which legislate openness and altruistic donation include Sweden, since $1985,{ }^{59}$ Victoria, Australia since $1998,{ }^{60}$ and the Netherlands since $2004 .^{61}$

For recent media speculation on donation rates and commercialization see Theresa Boyle, "He Was the Perfect Sperm Donor. Then 26 Families Found Out He Wasn't," The Toronto Star (9 April 2016), online: <https://www.thestar.com/life/health_wellness/2016/04/09/he-was-the-perfect-sperm-donorthen-26-families-found-out-he-wasnt.html>; Ëric Andrew Gee \& Theresa Boyle, "Everything You Wanted to Know - and Some Things You Didn't - About Sperm Donation," The Toronto Star (7 April 2015), online: <https://www.thestar.com/news/gta/2015/04/07/everything-you-wanted-to-know-andsome-things-you-didnt-about-sperm-donation.html>; QMI Agency, "Canada Facing a Shortage of Homegrown Sperm: Report,” The Toronto Sun (1 March 2011), online: $<$ http://www.torontosun.com/ life/healthandfitness/2011/03/01/17454786.html>.

54 Alison Motluk, "The Human Egg Trade," The Walrus (12 April 2012); Katie Hammond, "Canada's Online Human Egg Market” (2013) 19 The Scholar 9. With the advent of egg freezing it is unclear if this grey market in eggs will continue to thrive.

$55 \quad$ Downie \& Baylis, supra note 45.

$56 \quad$ K Daniels et al, "Sperm Donation: Implications of Canada's Assisted Human Reproduction Act 2004 for Recipients, Donors, Health Professionals, and Institutions" (2006) 28:7 J Obstetrics \& Gynaecology Can 608 .

$57 \quad$ Vanessa Gruben, "Freezing as Freedom? A Regulatory Approach to Elective Egg Freezing and Women's Reproductive Autonomy” (2017) 54:3 Alta L Rev 753.

58 Eric Blythe \& Lucy Frith, "Donor-Conceived People's Access to Genetic and Biological History: An Analysis of Provisions in Different Jurisdictions Permitting Disclosure of Donor Identity" (2009) 23:1 Intl JL Pol'y \& Fam 174 at 175 [Blythe \& Frith, "Access to Genetic and Biological History"].

Ken Daniels \& Othon Lalos, "The Swedish Insemination Act and the Availability of Donors" (1995) 10:7 Human Reproduction 1871.

$60 \quad$ Blythe \& Frith, "Access to Genetic and Biological History," supra note 58 at 177.

${ }_{61}$ A Brewaeys et al, “Anonymous or Identity-Registered Sperm Donors? A Study of Dutch Recipients' Choices" (2005) 20 Human Reproduction 820. 
The UK's Human Fertilisation and Embryology Act 2008, ${ }^{62}$ much like the AHRA, banned the sale of gametes and set in place a licensing regime which governs the practice of fertility medicine. ${ }^{63}$ In 2008, as part of a legislative overhaul, the UK banned anonymous gamete donation and set a fixed fee for the reimbursement of sperm and egg donors. ${ }^{64}$ Following an initial dip in the number of gamete donors, the number of donors has levelled out in this jurisdiction. ${ }^{65}$ This is due in part to targeted publicity campaigns ${ }^{66}$ seeking more mature gamete donors. As a result, sperm donor profiles have reportedly gone from "young men donating for 'beer money' pre-2005, to young professional males with families donating purely for altruistic reasons post-2005."67

\section{FAMILY LAW REFORM}

The third obstacle is embedded in the current family law regimes in various provinces. Where provinces have not revised their family law statutes to reflect the use of donated gametes in family building (for example, including a presumption that a gamete donor is not a parent), many Canadians have advocated in favour of donor anonymity. They see the use of an anonymous donor as offering protection against the potential interference by the donor in the family unit. Comprehensive family law reform, which occurred in jurisdictions such as the UK and Sweden, will eliminate this obstacle.

The use of ARTs in family building affects different families in different ways. Comprehensive family law reform must take into account the range of challenges facing Canadian families. For women-led families, updating parental status laws will allow them to form autonomous family units without the insertion of a sperm donor as an unwanted legal parent. ${ }^{68}$ For three parent families, clear parentage laws would allow them to attach legal rights to all three de facto parents. ${ }^{69}$ For opposite sex couples, more open donor policies and clear lines around who is and who is not a parent may go some distance towards alleviating the stigma associated with third party reproduction. ${ }^{70}$ Until comprehensive family law reform becomes a reality, intended parents will continue to turn to anonymous gametes as the most legally secure model of family formation.

Human Fertilisation and Embryology Act 2008, c 22.

Eric Blythe, "Implementing and Altruistic Sperm Donation Program in Canada" (2011) 33 J Obstetrics and Gynecology Can 485. Although disclosure of identifying information for gamete donors has been mandated since 2005. Eric Blythe \& Lucy Frith, "The UK's Gamete Donor 'Crisis': A Critical Analysis" (2008) 28:1 Critical Social Policy 74 [Blythe \& Firth, "Gamete Donor Crisis"].

$64 \quad$ See supra note 63.

65 Dr. Kamal Ahuja, "Is the UK Sperm Shortage a Myth?," BioNews (18 May 2015), online: <www. bionews.org.uk/page 526622.asp>.

66 BBC News, "UK National Sperm Bank Has Just Nine Donors," BBC News (1 September 2015), online: $<$ www.bbc.com/news/health-34113080>.

67 Arit Udoh, "Debating Donor Conception 10 Years After the Removal of Anonymity," BioNews (9 November 2015), online: <www.bionews.org.uk/page_583995.asp>.

68 See Cameron, "A Chip Off the Old (Ice) Block," supra note 13; Angela Cameron, "Regulating the Queer Family: The Assisted Human Reproduction Act," Case Comment, (2008) 24:1 Can J Fam L 101. Cameron, "A Chip Off the Old (Ice) Block," ibid.

Lucy Blake, Elena Ilioi \& Susan Golombok, "Thoughts and Feelings About the Donor: A Family Perspective" in Susan Golombok et al, Regulating Reproductive Donation (Cambridge: Cambridge University Press, 2016) 293 at 293. 


\section{A. Ontario as a Case Study}

Let us take Ontario as an example. This province is home to the largest number of fertility clinics in Canada. There, as in most other jurisdictions, parental status is vital from a legal perspective. Parental status allows the parent to fully participate in the child's life. The declared parent determines lineage and citizenship, and ensures that the child will inherit on intestacy. A declared parent may obtain a health card for the child, a social insurance number, purchase airline tickets, obtain a passport for their child, and register them at school. Only a declared parent may assert her rights under various laws, such as the Health Care Consent Act. ${ }^{71}$ Ontario has recently undertaken extensive family law reform to take donor gametes into account. Most Canadian provinces have not.

In Ontario, outdated family laws have recently been revised to reflect third party reproduction. The legal status of a person who donates sperm, eggs, or embryos is now defined by statute. ${ }^{72}$ Prior to these amendments, there were many legal questions about how to register the birth of a child born as a result of third party reproduction and who was the legal parent of such a child.

Until December 2016, law reform had been piecemeal and was driven by litigation on the part of families using third party gametes. After constitutional litigation, Ontario courts allowed parentage declarations for same-sex couples. ${ }^{73}$ Individuals who used a known donor prior to the amendments had to have a court issue a declaration of parentage to the intended parents; this was not done automatically upon the birth of a child. While these were most often done on consent, they still required judicial discretion and were costly for parents. ${ }^{74}$

Prior to December 2016, Ontario courts undertook to recognize new family forms resulting from third party reproduction, but only on a case-by-case basis. In A.A. v. B.B., the Court of Appeal granted parental status to the lesbian intended parents (biological mom and non-biological mom) and a sperm donor who was acting as a de facto parent. ${ }^{75}$ However, to do so, the Court of Appeal was forced to rely on their inherent jurisdiction to grant parental status to all three parties. Following the amendments, three parent families can be legally recognized with no court order. ${ }^{76}$

Most concerning are disputes between the intended parents and known donors. Until December 2016, in Ontario there was no law stating who was a donor and who was a parent, and therefore there was no legal protection for intended parents who did not want donors to be considered parents. The significance of this glaring gap was seen in a recent case in Ontario between a lesbian couple and a known sperm donor. ${ }^{77}$ The sperm donor wanted access to the child against the wishes of the lesbian couple. The case was settled out of court but brought into stark relief the potentially high stakes of using a known donor for women-

Health Care Consent Act, SO 1996, c 2.

Children's Law Reform Act, supra note 37, Part I.

Rutherford v Ontario (Deputy Registrar General) (2006), 81 OR (3d) 81.

See Joanna Radbord, "Same-Sex Parents and the Law" (2013) 33 Windsor Rev Legal Soc Issues 1.

2007 ONCA 2, 83 OR (3d) 561.

Children's Law Reform Act, supra note 37, s 9.

WW $v$ XX \& YY, 2013 ONSC 1509, 2013 ONSC 1509 (CanLII). 
led families in legal climates that have not been reformed to take third party reproduction into account.

Canada is now a patchwork of legal parentage rules relating to assisted human reproduction. While Ontario and British Columbia have comprehensive legislation which addresses the legal status of intended parents and gamete donors in the context of single mothers by choice, lesbian couples, and three parent families, ${ }^{78}$ effectively eliminating this barrier to open gamete donation, many others do not.

\section{THE CHARTER}

The fourth obstacle is Canada's Charter. Some donor-conceived people have turned to the courts as a way to address the legislative inaction on donor anonymity. These litigants have argued that the legislature's failure to prohibit the use of anonymous third party sperm and eggs, violates their Charter protected rights. To date, these efforts to use the Charter to eliminate donor anonymity in Canada have been unsuccessful. Past Charter cases have made it very difficult for donor-conceived people to successfully argue that the Charter protects an individual right to receive certain information about one's biological progenitors.

Olivia Pratten was born to an opposite sex couple using sperm from an anonymous donor. ${ }^{79}$ Pratten had very little information about the sperm donor, and the donor's medical records were destroyed by the physician who treated her mother. ${ }^{80}$ She had long searched for information about the sperm donor but was unable to gather any information about him. She eventually brought a lawsuit against the province. She raised two constitutional arguments. Both arguments would have effectively resulted in the end of donor anonymity in Canada. ${ }^{81}$

First, Pratten argued that section 7 of the Charter protects a freestanding constitutional right to know one's genetic origins which requires the provincial government to provide donor-conceived people with both identifying and non-identifying information about their donors. In the alternative, Pratten argued that the provincial rules authorizing the destruction of medical records after six years, including the medical records of sperm donors, violates her right to physical and psychological security of the person. ${ }^{82}$

These arguments were unsuccessful at both the trial and appeal courts. Both courts dismissed the free-standing rights argument out of hand. Although Canadian courts have left open the possibility, the courts have refused to extend section 7 to protect positive rights. ${ }^{83}$ Instead, section 7 of the Charter has been limited to protecting individuals from state action causing a deprivation of their right to life, liberty or security of the person. The Court of Appeal did, however, consider Pratten's substantive argument, but concluded that:

Family Law Act, supra note 37, Division 2; Children's Law Reform Act, supra note 37. Pratten v British Columba (AG), 2012 BCCA 480, 357 DLR (4th) 660 [Pratten], rev'g Pratten v British Columba (AG), 2011 BCSC 656, 2011 BCSC 656 (CanLII) [Pratten BCSC].

Ibid at para 3 .

It was, in fact, a similar case in the UK that acted as a catalyst for law reform there. See Blythe \& Firth, "Gamete Donor Crisis," supra note 63 at 76.

This argument was raised at trial. Justice Adair dismissed it on the basis that "there is insufficient state action to support Ms. Pratten's s. 7 claim, I do not need to address whether there has been a deprivation contrary to the principles of fundamental justice." Pratten BCSC, supra note 79 at para 315. Canadian Doctors for Refugee Care v Canada (AG), 2014 FC 651, 28 Imm LR (4th) 1. 
[a]ssuming that s. 7 of the Charter is capable of guaranteeing positive rights, and accepting that there has been movement in Canada and elsewhere toward more openness with respect to the type of information Ms. Pratten seeks, I am not persuaded that the right "to know one's past" is of such fundamental importance that it is entitled to free-standing constitutional recognition. ${ }^{84}$

Even if Pratten could overcome this positive rights hurdle, there are several legal obstacles with the constitutional protection of a right to know one's genetic origins. First, it will be challenging for a court to define the scope of this right; does it include just identity? Does it include access to non-identifying information or identifying information? Does it include the right to know the manner of one's conception $?^{85}$ Second, the recognition of such a constitutional right will need to overcome the robust legal protection afforded to individual privacy in Canadian law generally and also in the context of adoption.$^{86}$ Indeed, the Ontario courts have consistently refused to extend such constitutional protection to adoptees. ${ }^{87}$ Further, the right to know one's genetic origins also raises questions about whether such a right could create a legal obligation to disclose information retroactively. ${ }^{88}$ Finally, the implications of such a right may be wide-ranging and could support arguments in favour of similar situations including a legal obligation to declare the identity of the biological father on a child's birth certificate, to advise an individual who is mistaken as to the identity of their biological father, or to advise family members of relevant health information. ${ }^{89}$

Second, Pratten argued that British Columbia's Adoption Act ${ }^{90}$ is under inclusive and therefore violates section 15 of the Charter. The Adoption Act establishes a mechanism through which adoptees can access certain information about their birth parents. The Adoption Act requires the collection of information about the medical and social history of the adoptee's family, it provides for the creation of openness agreements between the adoptee and the biological family, and it provides adoptees who have been adopted after 1996 (the date the Adoption Act was amended) with the opportunity to learn the identify of their biological parents. ${ }^{91}$ The adoption registry is restricted to adoptees; it does not extend to gamete donors and donor-conceived people.

Pratten's section 15 argument was successful before the trial court. The British Columbia Supreme Court concluded that adoptees and donor-conceived individuals are similar and that their exclusion from the Adoption Act resulted in discrimination. ${ }^{92}$ In her view, the Adoption Act did not constitute ameliorative legislation and as such was not protected by section 15(2)

Pratten, supra note 79 at para 62.

See Lisa Shields, "Consistency and Privacy: Do These Legal Principles Mandate Gamete Donor Anonymity?” (2003) 12:1 Health L Rev 39.

Vanessa Gruben, "A Number but No Name: Is There a Constitutional Right to Know One's Sperm Donor in Canadian Law?" in Trudo Lemmens et al, eds, Regulating Creation: The Law, Ethics, and Policy of Assisted Human Reproduction (Toronto: University of Toronto Press, 2017) 145 at 157 [Gruben, "A Number but No Name"].

See Cheskes v Ontario (Attorney General) (2007), 87 OR (3d) 581 (Sup Ct J).

Gruben, "A Number but No Name," supra note 86 at 161.

Wanda Wiegers, "Fatherhood and Misattributed Genetic Paternity in Family Law" (2011) 36:2 Queen's LJ 623; Gillian Nycum, Bartha Marie Knoppers \& Denise Avard, "Intra-Familial Obligations to Communicate Genetic Risk Information: What Foundations? What Forms?” (2009) 3 McGill JL \& Health 21 .

RSBC 1996, c 5 .

For individuals adopted before 1996, identifying information may only be disclosed with the consent of both the adoptee and the birth parent(s).

Pratten BCSC, supra note 79 at para 268. 
of the Charter. ${ }^{93}$ Further, Justice Adair concluded the violation was not saved by section 1 of the Charter. The Attorney General of British Columbia argued that the omission of donorconceived individuals from the adoption legislation was a pressing and substantial objective because they are not adopted and are provided for under the AHRA. Justice Adair concluded that the Attorney General failed to "establish that the objective of the omission of donor offspring was or is pressing and substantial." ${ }^{94}$ She concluded that not only had the AHRA not come into force at the commencement of the litigation, the information and disclosure provisions had been declared unconstitutional by the time she rendered her decision. She further reasoned that she was unaware of any case "where a province has been allowed to justify under inclusive legislation on the grounds of federal legislation, where there was no duplication and the province has jurisdiction to legislate." 95

By contrast, the Court of Appeal concluded that the information provisions for adoptees fall within the scope of section 15(2) of the Charter, which protects ameliorative legislation, and therefore are not subject to the same scrutiny as other forms of legislation. ${ }^{96}$ The Court of Appeal explained that "it is open to the Legislature to provide adoptees with the means of accessing information about their biological origins without being obligated to provide comparable benefits to other persons seeking such information." ${ }^{97}$ As such, the Court of Appeal concluded that the Adoption Act did not result in discrimination against donorconceived people.

Although this issue was not considered by the Supreme Court of Canada (they refused to hear the appeal from the British Columbia Court of Appeal), it may be difficult for such a constitutional argument to succeed in light of the historical jurisprudence described above. ${ }^{98}$ In addition to the approach Canadian courts have been adopting towards section 15(2), there may be other jurisprudential obstacles to such an argument. For example, Justice Adair accepted the analogous ground of "mode of conception," which may pose difficulties "given that there has been little time to accumulate a pattern of exclusion or discriminatory thinking." 99

\section{CONCLUSION: Proposing a WAY ForWARd}

Removing obstacles to more open gamete donation requires a multifaceted approach, but it is possible and desirable. Donor anonymity and associated legal issues, in our view, are best dealt with comprehensively by the legislature. What are the next steps that should be

In Justice Adair's view, section 15(2) ensured that the government was not precluded by section 15(1) from enacting an ameliorative law or program. Thus, Justice Adair reasoned that section 15(2) did not apply because Pratten was not seeking to preclude the Province from enacting the Adoption Act, supra note 90, and the Adoption Regulation, BC Reg 291/96. In other words, she was not arguing that adoptees should not benefit from the legislation. Rather, Pratten was simply arguing that the legislation was under inclusive, and therefore discriminatory as a result of omitting donor offspring, and therefore section 15(2) was not engaged.

Pratten BCSC, supra note 79 at para 325.

Ibid at para 324 .

Pratten, supra note 79 at para 37.

Ibid at para 42.

See Vanessa Gruben \& Daphne Gilbert, "Donor Unknown: Assessing the Section 15 Rights of DonorConceived Offspring” (2011) 27:2 Can J Fam L 247.

Ibid at 267. 
undertaken? We propose that the way forward involves four aspects: provincial family law reform where necessary; robust and meaningful public consultation; interprovincial cooperation if possible; and, consideration of law reform in other jurisdictions.

First and foremost, the provinces must undertake family law reform that recognizes third party reproduction. As discussed above, family law reform is needed to protect the integrity of a range of families. ${ }^{100}$ For guidance, provincial legislatures may look to other provinces, such as Ontario, British Columbia, or the Uniform Law Commission of Canada for model legislation. ${ }^{101}$

Second, we believe robust and meaningful public consultation is required. To date, with the exception of Quebec, which carried out a review of the funding program, and British Columbia, which engaged with the public on some of the parentage issues, the legislatures have made little effort to consult with the public on AHR generally and gamete donation in particular. Ontario has struck two expert panels on assisted human reproduction, yet both have focused on funding and have primarily included clinicians. ${ }^{102}$ Wide public consultation will ensure that the diverse perspectives of all involved, donor-conceived persons, donors, and intended parents, are heard and accounted for in resulting law reform.

Third, while it is not necessary, we believe that interprovincial cooperation on this issue would be highly beneficial. In our view, the inaction of the provinces described above may be partly addressed by a coordinated provincial approach to law reform. This coordinated effort would ensure greater efficacy and would spread the cost of creating and maintaining an information registry across the provinces. ${ }^{103}$

Interprovincial cooperation on difficult issues in Canada is not uncommon. There is a high level of coordination between the various provinces regarding a number of issues including the regulation of organ donation. ${ }^{104}$ The responsibility for oversight of organ donation and transplantation falls to each of the provinces, which have managed this area of health care through the creation of organ donation organizations (ODOs). ${ }^{105}$ The Council for Donation and Transplantation (CCDT) was created to address concerns about fragmentation and efficiency, and has promoted a national strategy for organ donation and transplantation. ${ }^{106}$ In 2008, the organ donation and transplantation system became further centralized as a result of the merger between Canadian Blood Services and the CCDT, which in 2010 resulted in

See Part IV, above.

Uniform Law Conference of Canada, Uniform Child Status Act 2010, online: <www.ulcc.ca/en/ uniform-acts-new-order/current-uniform-acts/86-josetta-1-en-gb/uniform-actsa/child-status-act/1371child-status-act-2010>.

Expert Panel on Infertility and Adoption, Raising Expectations: Recommendations of the Expert Panel on Infertility and Adoption (Summer 2009), online: <www.children.gov.on.ca/htdocs/English/docu ments/infertility/RaisingExpectationsEnglish.pdf $>$. With respect to public funding, see Ministry of Health, "Advisory Process for Infertility Services Key Recommendations Report" (23 June 2015), online: <health.gov.on.ca/en/public/programs/ivf/docs/ivf_report.pdf> .

See Part III, above.

See Dave Unger, "Organ Donation" in The Canadian Bioethics Companion (2017), online: <canadian bioethicscompanion.ca/the-canadian-bioethics-companion/chapter-7-organ-donation/\#_ENREF_8_14>. Trillium Gift of Life Network Act, RSO 1990, c H.20.

Unger, supra note 104. 
the creation of a national registry for living kidney donation. ${ }^{107}$ This is an excellent model for interprovincial cooperation on a complex, poly-jurisdictional health issue.

Another example of interprovincial cooperation is the recent coordination on physicianassisted dying. Following the Supreme Court of Canada's decision in Carter v. Canada (Attorney General), ${ }^{108}$ a number of provincial governments joined together to create a provincial-territorial group on physician-assisted dying. ${ }^{109}$ This group was established to provide non-binding advice to participating Provincial-Territorial Ministers of Health and Justice on issues related to physician-assisted dying. Although the recommendations are not binding on provinces, the report generates important guidance and promotes a series of core recommendations that can be implemented across provinces while still allowing for variation between them. ${ }^{110}$

Fourth, we must look to other jurisdictions for guidance on the regulatory obstacles discussed above. In the past, Canada has looked to the UK for guidance. ${ }^{11}$ The UK struggled with some of the same issues we are currently facing in Canada, including the impact of donor anonymity on the supply of gametes and difficulties associated with cross-border reproductive trade in sperm and eggs. ${ }^{112}$ We have much to learn from the UK and other jurisdictions that have made considerable progress in creating a system based on a robust supply of identity release gametes. We should also look to other federal jurisdictions, for instance, Australia, where legislative action has occurred on a state-by-state basis, such as in Victoria and Western Australia. ${ }^{113}$ Canadian empirical research will also go some distance in ensuring we have a "made in Canada" approach that can take into account our polyjurisdictional challenges as well as our unique geopolitical landscape.

See e.g. Canadian Blood Services, "Backgrounder: Kidney Paired Donation Program," online: $<$ https://www.blood.ca/media/backgrounder-kidney-paired-donation-program>. 2015 SCC 5, [2015] 1 SCR 331.

Canada, Ministry of Health and Long-Term Care, "Provincial-Territorial Expert Advisory Group on Physician-Assisted Dying: Final Report" (30 November 2015), online: <www.health.gov.on.ca/en/news/ bulletin/2015/docs/eagreport_20151214_en.pdf>.

Ibid at 5-11.

Erin Nelson, Law, Policy and Reproductive Autonomy (Oxford: Hart, 2013) at 254.

See Part III, above.

Assisted Reproduction Treatment Act 2008 (Vic); Human Reproductive Technology Act 1991 (WA). 